\title{
Notes on Contributors - July 2012
}

\section{Rom Harré}

Rom Harré was for many years Lecturer in Philosophy of Science at Oxford University and is Fellow Emeritus of Linacre College. His career has moved from chemical engineering to mathematics to philosophy to psychology. Currently he is Distinguished Research Professor of Psychology at Georgetown University, Washington DC. His most recent books include Pavlov's Dogs and Schrodinger's Cat and Psychology for the Third Millennium with F. M. Moghaddam.

\section{Anik Waldow}

Anik Waldow is Lecturer in Philosophy at the University of Sydney. Her interests are centred on early modern philosophy, especially Hume. She has contributed to The British Fournal for the History of Philosophy, History of Philosophy Quarterly, Hume Studies, and other journals.

Stephen Hetherington

Stephen Hetherington is a Professor of Philosophy at the University of New South Wales, in Sydney, Australia. He is the author of several books, including Good Knowledge, Bad Knowledge (OUP, 2001), Self-Knowledge (Broadview, 2007), Yes, But How Do You Know? (Broadview, 2009), and How To Know (Wiley-Blackwell, 2011)

\section{Karyn Lai}

Karyn Lai is Associate Professor of Philosophy at the University of New South Wales, Sydney, Australia. Her primary research is in pre-Qin (pre-200 BCE) Confucian and Daoist philosophies. She is the author of Learning from Chinese Philosophies (Ashgate, 2006) and Introduction to Chinese Philosophy (Cambridge, 2008); and is editor of Philosophy Compass (Chinese Comparative Philosophy Section). 


\section{Notes on Contributors}

Daniel Robinson

Daniel N. Robinson is a member of the Philosophy Faculty, Oxford University, and Distinguished Professor, Emeritus, Georgetown University.

David Archard

David Archard is Professor of Philosophy at Queen's University Belfast having previously taught at the Universities of Ulster, St. Andrews and Lancaster. He is the author of several books and many articles in applied ethics, social, legal and political philosophy. His most recent books are The Family: A Liberal Defence (2010) and the co-edited Procreation and Parenthood: The Ethics of Bearing and Rearing Children (2010).

\section{Edward James}

Edward James is an Emeritus Professor of Philosophy at Bridgewater State University. He has published in such journals as Philosophy, Mind, and Ethics. His research has focused on the limits and powers of reasoning. 